$1-1-1971$

\title{
A cost analysis of the livestock auction markets in West Virginia
}

Maclellan E. Wilson

John P. Kuehn

Follow this and additional works at: https://researchrepository.wvu.edu/ wv_agricultural_and_forestry_experiment_station_bulletins

\section{Digital Commons Citation}

Wilson, Maclellan E. and Kuehn, John P., "A cost analysis of the livestock auction markets in West Virginia" (1971). West Virginia Agricultural and Forestry Experiment Station Bulletins. 600T.

https://researchrepository.wvu.edu/wv_agricultural_and_forestry_experiment_station_bulletins/701 @ WVU. It has been accepted for inclusion in West Virginia Agricultural and Forestry Experiment Station Bulletins by an authorized administrator of The Research Repository @WVU. For more information, please contact ian.harmon@mail.wvu.edu. 


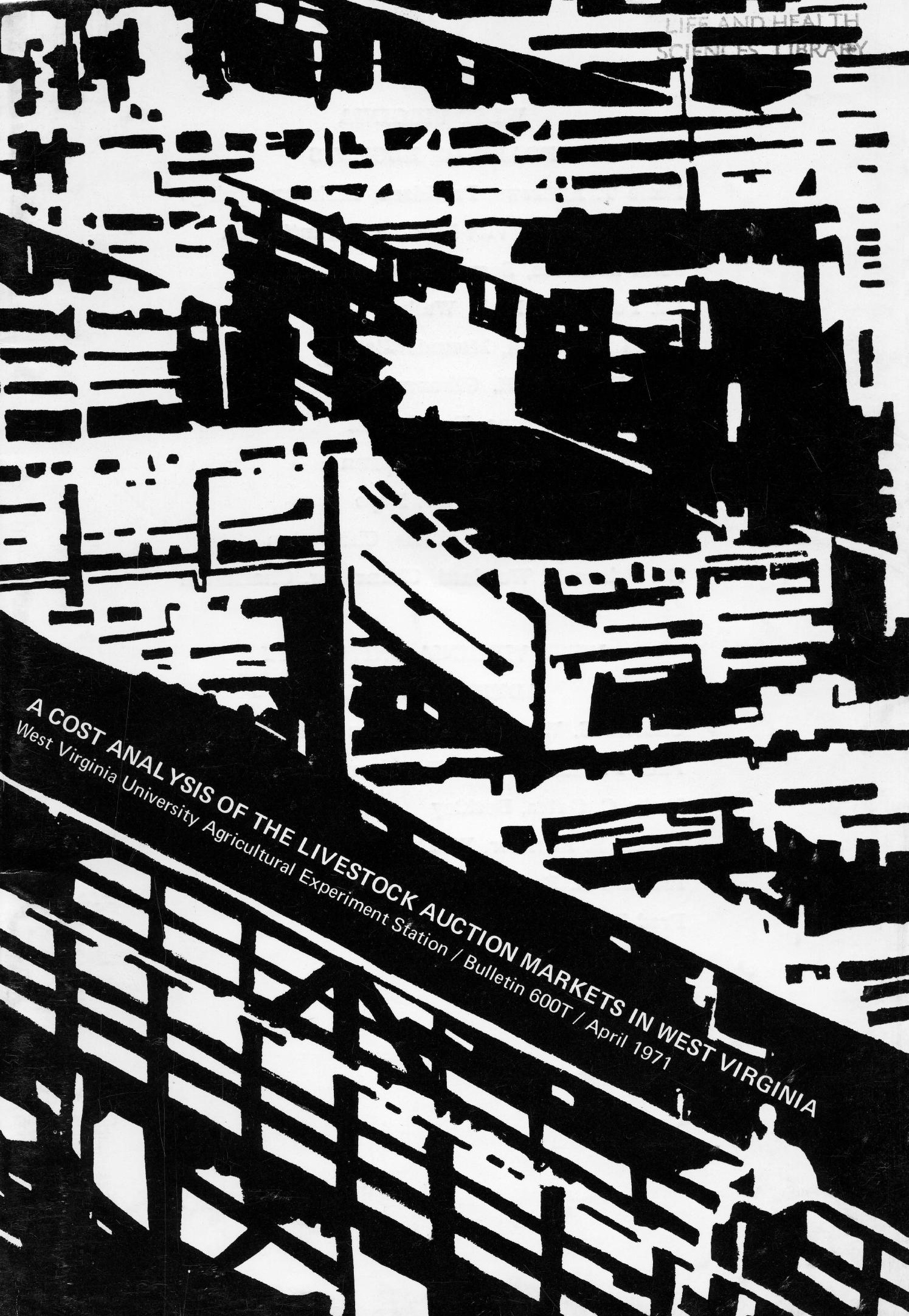




\section{WEST VIRGINIA}

\section{BOARD OF REGENTS}

Earle T. Andrews, President, Berkeley Springs

Amos A. Bolen, Vice-President, Huntington

John E. Amos, Secretary, Charleston

Dr. Forrest L. Blair, Walker

David B. Dalzell, Moundsville

Mrs. Elizabeth H. Gilmore, Charleston

Edward H. Greene, Huntington

Albert M. Morgan, Morgantown

Okey L. Patteson, Mount Hope

Daniel B. Taylor, ex officio, Charleston

Dr. Prince B. Woodard, Chancellor, Charleston

\section{WEST VIRGINIA UNIVERSITY}

\section{ADVISORY BOARD}

Charles C. Wise, Jr., Chairman, Charleston

Paul B. Martin, Vice-Chairman, Martinsburg

Leslie C. Gates, Beckley

Robert E. Mentzer, Weirton

Richard A. Raese, Morgantown

Fred R. Toothman, Huntington

Dr. A. J. Villani, Welch 


\section{CONTENTS}

Summary and Conclusions _............................................ 3

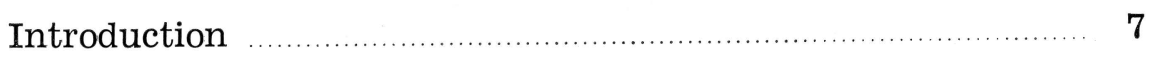

Statement of the Problem …........................................... 10

Research Method and Source of Data ................................... 11

Livestock Marketing Research in West Virginia ........................ 11

Characteristics of Auction Markets in West Virginia ................. 12

Auction Ownership ................................................... 12

Auction Market Facilities …......................................... 13

Receiving and Loading Facilities ................................... 13

Pens and Alleys ........................................................ 13

Handling and Care of Livestock Before Sale ................... 13

Sales Room ........................................................ 14

Sale Characteristics …........................................... 14

Livestock Auction Costs ................................................ 15

Estimation of Livestock Conversion Coefficients ................. 16

Comparison of Regression Coefficients with Actual

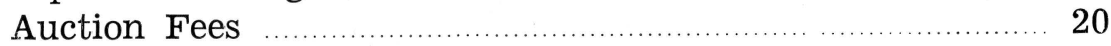

Analysis of Cost and Volume Data …................................. 20

Seasonal Variations in Livestock Marketing …...................... 21

Stratified Unit Cost Comparisons …...................................... 23

Statistical Unit Cost Comparisons …..................................... 23

Statistical Estimates of Cost Functions …............................ 24

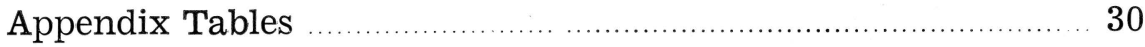

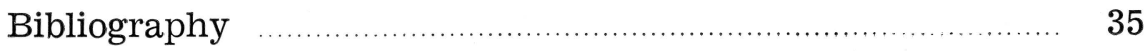




\section{THE AUTHORS}

E. Maclellan Wilson, at the time of this study, was a Graduate Research Assistant. John P. Kuehn is an Assistant Agricultural Economist.

West Virginia University Agricultural Experiment Station College of Agriculture and Forestry

A. H. VanLandingham, Director Morgantown 


\section{SUMMARY AND CONCLUSIONS}

The growth pattern of the West Virginia livestock auction sector is similar to that experienced nationally. Peak numbers of auction markets occurred in the 1950's; since that time, there has been a decline in the number of firms. Operating as auction market businesses do, on a competitive basis, it appears likely that a long-run market equilibrium must be achieved at the expense of the less efficient firms. The central problem area of this study was concerned with the estimation of costs per unit of market turnover for different size livestock auction firms in West Virginia. The statistical description method was used to determine the appropriate cost curves for an aggregate of markets in the State with the objective of ascertaining the most efficient size range in terms of cost, ceteris paribus.

During each of the two years encompassed by this study (1967 and 1968), there was a total of 20 livestock auctions operating as public markets in West Virginia. This study was based upon available data from the annual reports of individual auction markets as submitted to the State Department of Agriculture.

A regression equation was used to derive a livestock marketing unit ratio of 1 cattle: 3 calves: 4 hogs: 5 sheep or lambs, which allowed the conversion of heterogeneous species into common livestock marketing units (LMU's), on the basis of the contribution of each species to market costs. Average costs were obtained by dividing total auction market costs by the number of livestock marketing units handled by a firm in a given year. Results indicated that mean average costs for firms handling less than 6,000 LMU's were $\$ 4.70$ per LMU; for firms handling between 6,000 and 11,999 LMU's, mean average costs were $\$ 3.83$ per LMU; and for firms of 12,000 LMU's and over, mean average costs were $\$ 3.59$ per LMU. These apparent economies of size were verified by means of direct statistical analysis of market costs which indicated significant cost economies occurred as volume increased toward 6,000 LMU's per annum. Beyond this point cost economies were not as great, though smaller unit cost advantages did accrue with increasing firm size.

The study indicated the major cost component for all markets was that of labor. The data available for West Virginia auction firms showed that labor costs of $\$ 2.36$ per LMU constituted, in aggregate, some 58 per cent of total unit costs ( $\$ 4.09$ per LMU). By contrast, unit maintenance and repair costs (9 cents per LMU) 
constituted a relatively small proportion of total unit costs, and together with the small cost fraction (less than one per cent) assigned to capital improvement, indicated the reluctance of auction operators to commit funds to the expansion of market facilities. In fact, auction markets, due to the specialized nature of operations and a tendency towards asset fixity are conceivably in the position where they will resist liquidation so long as revenues exceed variable market costs. As time progresses, it seems likely that the less efficient firms will be forced out of business. However, such a decrease in the number of firms is not necessarily in accord with the needs of the various groups presently using the auction services. The needs of farmers, for instance, are somewhat in conflict with the needs of packers and order buyers. Where the latter groups would prefer fewer and larger auctions that would enable them to obtain livestock in large uniform lots from one source, farmers would frequently choose to have access to competitive market outlets, well located with reference to the point of livestock production.

Extreme seasonality in the volume of livestock marketing was demonstrated in the study, and this phenomenon was manifested in the problem of under-utilization of plant capacity. Since an auction firm must have sufficient facilities to handle the maximum seasonal turnover, under-utilization of facilities occurs during the off-season which comprises about nine months of the year.

It appears then, that those firms handling more than 6,000 LMU's per annum enjoy distinct cost advantages over the smaller firms in West Virginia. Furthermore, it appears that under conditions of increased capacity utilization, a downward shift of the long-run average cost curve would be likely. These generalized findings suggest potential areas for decreasing costs. Some measures which could decrease costs in the industry include:

1. increasing livestock marketing volume in the State or adjusting the mix between firms of existing volumes to take advantage of economies of size;

2. increasing the level of competition between firms by adjusting the regulation of commission fees and allowing more than one sales day per week per firm; and

3. an increase in economic and physical efficiency of the industry which could result from fewer and larger firms, more efficiently located, i.e., more efficient allocation of human and capital resources. 
These measures are easier described than implemented. They are relatively long term means of correcting contemporary problems. They can be effective as cost-reducing measures, but a cost reduction is only effective when there is no corresponding reduction in price or gross revenue.

Increasing the number of livestock marketed through auctions may come about by increasing total production in the State or by improving the economic perspective of auction markets relative to other channels of marketing. Allowing competition to seek its own level (by relaxing government control of auction pricing and sales practices) may be one means of improving the economic perspective of some auction facilities. Allowing competition to increase may also have the effect of more efficiently allocating the human and capital resources of the auction sector. An improved State highway system (now under construction) is another important factor which could have this effect.

The three measures suggested above are interrelated and the feasibility of implementing one or more of them may be questionable under the present institutional framework of the State. It is also fairly safe to assume, that based on the trends in the industry towards fewer, larger, and more efficient firms, that the suggested improvement will come about over time at least partially without any external form of intervention.

However, an improvement in the livestock auction sector at this time may improve the relative strength of the State livestock industry as a whole. The measures suggested in this study could initially improve the economic position of some individual auction market operators. With fewer and larger auction markets, then, revenues to livestock producers could increase. Lot sizes would be larger, attracting more buyers, and in some cases, larger lot sizes of uniform animals bring higher prices. These higher prices could, however, be attenuated by higher assembly costs (from farm to the auction market) since the reduced number of auction markets would be more widely dispersed.

It can be deduced from these conclusions that the actual effects on the industry of the implementation of one or more of the above measures are not known with certainty. In order to rectify this situation, research is now underway to determine more specifically what the actual economic situation is and how to improve it. 
Blank Page in Original Bulletin 


\section{A Cost Analysis of the Livestock Auction Markets in West Virginia}

E. MACLELLAN WILSON and JOHN P. KUEHN

The historical evolution of the U. S. economy has been associated with a parallel and interrelated development of the Nation's livestock sector. During the frontier period, railroads came to dominate the transportation scene, and indeed the rapid encroachment of the "iron horse," catalyzed partly by the American Civil War, provided a climate conducive to the establishment of large terminal markets at strategic points in the Midwest. ${ }^{1}$ During the latter half of the nineteenth century, stockyards opened in Chicago (1865), Kansas City (1871), St. Louis (1872), Cincinnati (1874), Indianapolis (1877), Omaha (1884), Denver (1886), St. Paul (1888), Fort Worth (1893), Sioux City (1894), and St. Joseph (1896). . However, the ensuing system of livestock marketing was tied to the rails and in this respect exhibited a certain degree of inflexibility.

Williams and Stout have suggested three reasons that prompted the move away from centralized marketing:

1. less-than-carload freight rates that the individual farmer found prohibitive,

2. complaints of low livestock prices, and

3. the suspicion that dealer operating margins were unjustifiably wide."

Changes in the marketing structure gained momentum in the early part of the twentieth century. Williams and Stout state:

Out of World War I came the truck, a war-tested vehicle of unforseeable usefulness and significance. Other developments were to come: automobiles; a network of roads and highways; a growing population; growing cities that spread and enveloped terminal stockyards once located on the out-skirts; thriving retail grocery chains and supermarkets-a totally new concept in self service-. . .

${ }^{1}$ For a more complete discussion of the historical development of the livestockmeat industry see Willard F. Williams and Thomas T. Stout, Economies of the Livestock-Meat Industry (New York: The Macmillan Company, 1964), ch. 1.

${ }^{2}$ Edward Uvacek and Dalton L. Wilson, Livestock Terminal Markets in the United States, Agricultural Marketing Service, U. S. Department of Agriculture, Marketing Research Report No. 299 (Washington: U. S. Government Printing Office, 1959), p. 2.

${ }^{3}$ Williams and stout, op. cit., p. 22.

${ }^{4}$ Ibid., p. 24. 
Thus the 1930's witnessed a dynamic growth in the number of livestock auction markets. Phillips and Engelman have noted that:

About 200 auctions are estimated to have been operating by 1930 . The first complete count made in 1937 indicated 1,345 auctions were operating in the United States. Another count showed 2,472 operating in 1949. The peak in numbers was reached in 1952 when over 2,500 different livestock auctions were holding sales. Another complete count in 1955 showed that auction numbers had declined to 2,322 .

A similar pattern of growth occurred for West Virginia auctions. Abrahamsen recorded that: "the first auction to be organized was the Spencer Livestock Exchange, chartered February 11, 1932." "' In 1956 another study indicated that: "sixteen of West Virginia's auctions were organized in the period 19321938. Six were established in the 1940's, and the last one in 1950." Thus by 1950 there was a total of 23 auctions operating in the State, although in 1968 this number had declined to 20 (Appendix Table 1), and in 1969 one additional market closed down. An appropriate description of the growth characteristics exhibited by West Virginia's livestock auctions emerges from the observation that:

The first sign of a new industry is its inception period followed by a period of rapid growth, both in numbers and capacity. Following this rapid expansion is the leveling off period as demand for their services is fulfilled. Finally, a decline in the number of firms materializes as low volume firms with high unit costs cease to exist as competition between firms for the available market increases.

During the 1960's the decline in the number of auction markets in the State was accompanied by a concurrent decline in the volume of marketings (Table 1) and in the farm inventory of livestock (Table 2). Table 1 shows, for example, that in the years

${ }^{5}$ Victor B. Phillips and Gerald Engelman, Market outlets for Livestock Producers, Agricultural Marketing Service, U. S. Department of Agriculture, Marketing Research Report No. 216 (Washington: U.S. Government Printing Office, $1958)$, p. 8.

${ }^{6}$ M. A. Abrahamsen, Livestock Marketing Agencies in West Virginia, West Virginia Agricultural Experiment Station, Bulletin 312 (Morgantown, December, $1943)$, p. 57.

${ }^{7}$ C. G. Randell, Livestock Auctions in the Northeastern States, U. S. Department of Agriculture, Farmer Cooperative Service Bulletin 8 (Washington: U. S. Government Printing Office, 1956), p. 41.

${ }^{8}$ R. C. Lindberg and G. G. Judge, Estimated Cost Functions for oklahoma Livestock Auctions, Oklahoma Agricultural Experiment Station, Bulletin B-502 (Oklahoma State University, January, 1958), p. 7. 
TABLE 1

LIVESTOCK MARKETED THROUGH WEST VIRGINIA AUCTIONS, BY CLASS: $1961-1968^{a}$

\begin{tabular}{lcrc}
\hline \hline Year & Cattle and Calves & Hogs & Sheep and Lambs \\
\hline $1961^{\text {b }}$ & 252,705 & 64,553 & 167,702 \\
1962 & 265,201 & 71,799 & 163,179 \\
1963 & 264,137 & 69,618 & 147,819 \\
1964 & 258,195 & 61,528 & 125,845 \\
1965 & 270,523 & 51,883 & 121,194 \\
1966 & 234,332 & 56,112 & 117,488 \\
1967 & 192,396 & 54,880 & 112,431 \\
1968 & 197,444 & 55,044 & 108,476 \\
$1961-1965$ & & & \\
Average & 262,152 & 63,876 & 145,147 \\
1968 as \% of & & & \\
$1961-1965$ Average & 75.32 & 86.17 & 74.74 \\
\hline
\end{tabular}

aSource: From Annual Reports of Livestock Auction Markets to the West Virginia Department of Agriculture, 1961-68.

${ }^{\mathrm{b}} \mathrm{Tw}$ o markets out of 22 did not report.

TABLE 2

LIVESTOCK INVENTORY, WEST VIRGINIA, BY NUMBER ON HAND JANUARY 1, 1961-1968 ${ }^{\mathrm{a}}$

\begin{tabular}{lccc}
\hline \hline Year & Cattle and Calves & Hogs & Sheep and Lambs \\
\hline 1961 & 535,000 & 95,000 & 275,000 \\
1962 & 530,000 & 83,000 & 256,000 \\
1963 & 514,000 & 82.000 & 241,000 \\
1964 & 504,000 & 73,000 & 214,000 \\
1965 & 494,000 & 62,000 & 205,000 \\
1966 & 459,000 & 54,000 & 191,000 \\
1967 & 427,000 & 60,000 & 178,000 \\
1968 & 448,000 & 62,000 & 173,000 \\
$1961-1965$ & & & \\
Average & 515,000 & 79,000 & 238,000 \\
1968 as \% of & & & \\
$1961-65$ Average & 86.99 & 78.48 & 72.69 \\
\hline
\end{tabular}

aSource: 1961-1967 data from West Virginia Department of Agriculture, 1968 West Viroinia Agricultural Statisties, West Virginia Crop Reporting Service, C. R. Bulletin No. 7 (Charleston: February, 1968), pp. 17, 19, and 20. Data for 1968 were from United States Department of Agriculture, Livestock and Poultry Inventory, January 1: Number, Value, and Classes, Crop Reporting Board, Statistical Reporting Service, U. S. Department of Agriculture (Washington: U. S. Department of Agriculture, February, 1969), pp. 9, 10, and 14. 
1966, 1967, and 1968, as compared with a 1961-1965 average, there was a decrease in the numbers of the main classes (cattle and calves, hogs, and sheep and lambs) disposed through auction sales. For the ruminant members of these main classes, the 1968 figure was some 25 per cent below the 1961-1965 average, and for hogs the 1968 figure was nearly 14 per cent below the 1961-1965 average. The inventory of livestock on West Virginia farms displayed a similar decline. Thus in Table 2, the 1968 figure for numbers on hand expressed as a percentage of the 1961-1965 average was 86.99 for cattle and calves, 78.48 for hogs, and 72.69 for sheep and lambs. Data are available which confirm the downward secular trend for hogs, and for sheep and lambs over a much longer period, but these data also indicated that cattle and calf production experienced a generally rising trend up to the 1960's.' This inconsistency, with respect to cattle and calves in the years 1966, 1967, and 1968, may well be explained as a cyclical phenomenon.

\section{STATEMENT OF THE PROBLEM}

The decline in numbers of livestock auction markets operating in West Virginia during the 1960's reflected an era of increased competition for the available market." This decline leads one to suspect that there is an excess of firms in the livestock marketing sector under present conditions. The objective of this study was to evolve a broad economic sketch of livestock auctions in West Virginia in terms of relationships between the annual marketing volumes and unit costs; to relate this relationship to the theoretical notion of economies of size; and to evaluate selected institutional variables for different size firms. Specific objectives were:

1. to evolve livestock species conversion coefficients which could be used to rank different sized auctions on a homogeneous base,

2. to estimate the statistical parameters which approximate appropriate unit cost functions,

\footnotetext{
${ }^{9}$ Secular trends for the period 1867 to 1954 may be found in W. S. Hutson, Livestock Marketing Practices of West Virginia Farmers, West Virginia University Agricultural Experiment Station, Bulletin 384 (Morgantown, December, 1955), pp. 6-8. For data through 1960 see Mary E. Templeton, Statistical Chartbook of West Virginia Agriculture, West Virginia Agricultural Experiment Station, Current Report 51 (Morgantown, March, 1967), pp. 12 and 16.

${ }^{10}$ One market ceased operation in 1965, one in 1966, and one in 1969 .
} 
3. to examine the hypothesis that cost economies will be found within the range of different sized markets, and

4. to discuss the influence of relevant institutional variables on operational efficiency.

\section{RESEARCH METHOD AND SOURCE OF DATA}

The statistical description method was used to accomplish the objectives of this study. Cross section data for two years (1967-1968) were used to yield a broad cost-volume relationship for the livestock auctions of the State.

The primary source of data for this study was the 1967 and 1968 Annual Reports of West Virginia livestock auction markets to the Commissioner of Agriculture in Charleston. Auction operators are required by law to submit business records to the State Department of Agriculture each year. These records include information on livestock volume turnover by species for each sale, and cost figures by specified categories per annum. Supplementary information was obtained from existing literature on livestock marketing, and from direct liaison with local representatives of the State Department of Agriculture and with members of the Cooperative Extension Service of West Virginia University who maintain close contact with individual auction firms.

\section{LIVESTOCK MARKETING RESEARCH IN WEST VIRGINIA}

At the time of this study, there was a limited amount of upto-date information on livestock auction markets in West Virginia. There were, however, a few studies which provided some data information on the historical evolution of the industry. Abrahamsen, for instance, conducted an extensive survey of the "operating practices followed by livestock marketing agencies in West Virginia." In discussing the operating statements of a sample of the auction firm population, he noted that:

The larger auctions returned about one-half cent more per dollar of sales to consignors and operated at a cost of about one-half cent less per dollar of sales. Net income was 0.71 cents per dollar of total sales for the larger auctions as compared with 0.46 cents for the smaller ones. ${ }^{12}$

\footnotetext{
${ }^{11}$ M. A. Abrahamsen, Livestock Marketing Agencies in West Virginia, West Virginia Agricultural Experiment Station, Bulletin 312 (Morgantown, December, 1943 ).

${ }^{12}$ Ibid., p. 73. Size of auctions in terms of annual dollar sales.
} 
With regard to expense items, this study also indicated that:

Wages, bonuses, and salaries accounted for approximately one-half of total expenses. Officers' and directors' salaries accounted for another one-tenth of total expenses, making a combined total of about 60 percent of the total expenses for all salaries and wages. Except for taxes, the next most important item was operating and trading loss. . . It is significant that in practically every instance, auctions lost money on their trading operations. This does not mean, however, that persons connected with auctions lost money when operating as individuals. ${ }^{13}$

A subsequent study by Hutson investigated "the livestock marketing practices of West Virginia farmers." "While it would be naive to assume that the situation has been static over the last two decades, it is of interest that in 1950 a sample survey by Hutson indicated that: "approximately two-thirds of the cattle and calves, slightly more than one-half of the hogs and pigs, and twothirds of the sheep and lambs marketed from West Virginia farms were sold through auctions." ${ }^{15}$ This study also underlined the seasonal nature of livestock marketing by tracing seasonal fluctuations in volume. For sheep, where the largest variation occurred, the study showed "90 percent of the reported sales concentrated in July, August, September, and October."

\section{CHARACTERISTICS OF AUCTION MARKETS IN WEST VIRGINIA}

\section{Auction Ownership}

In each of the two study years, 1967 and 1968, there were 20 livestock auctions in West Virginia. Classified by type of business ownership, 17 firms were organized as corporations. Of those remaining, one firm operated on an individual proprietorship basis, one as a partnership, and one as a cooperative enterprise. Under the terms of the statutory provisions of West Virginia, an annual permit was required to operate a public market regardless of type of ownership. ${ }^{17}$ Furthermore, before the permit could

\footnotetext{
${ }^{13}$ Ibid., pp. 75-76.

${ }^{14}$ W. S. Hutson, Livestock Marketing Practices of West Virginia Farmers, West Virginia University Agricultural Experiment Station, Bulletin 384 (Morgantown, December, 1955).

15 Ibid., p. 3.

${ }^{16}$ Ibid., p. 25

${ }^{17}$ West Virginia Department of Agriculture, Laws of West Virginia Relating to Agriculture and Veterinarians (Charleston: West Virginia Department of Agriculture, 1965), p. 9, reprinted from Michie's West Virginia Code of 1961 and 1965 Cumulative Supplement.
} 
be issued, a surety bond payable to the State for the security of consignors was necessary. ${ }^{18}$

\section{Auction Market Facilities ${ }^{19}$}

The design of individual markets varied throughout the State, though all markets had the essentials for normal selling operations. These include a dock for receiving and loading, a system of pens and alleys for handling livestock, weighing facilities, grading and testing pens with a catching chute, sheep dipping facilities, watering facilities, office facilities, a sales room, and facilities for the public (rest rooms and drinking water supply). Additional features included some sort of food and refreshment service for the public, but restaurant facilities varied in sophistication from market to market.

\section{Receiving and Loading Facilities}

Most West Virginia auction markets used the same docks for receiving livestock and loading after sales. Generally speaking, these facilities were adequate to handle the normal volumes of livestock expected by markets. Although most livestock markets in the State have close access to railway facilities, this means of delivery and removal of livestock had been virtually replaced by truck transportation. Access roads were adequate to cope with truck traffic. However, the completion of the interstate highway system in West Virginia should greatly expedite movement of livestock.

\section{Pens and Alleys}

Due to the seasonal nature of livestock marketing, auction management is faced with the dilemma of providing adequate yard facilities for peak sales periods, commensurate with overall efficiency in off-peak seasons. In West Virginia auction markets, the pen facilities were well used in the fall, and only partially filled for the rest of the year. Pens were generally constructed of wood, and four of the markets in the State had overhead walkways for the benefit of prospective buyers.

\section{Handling and Care of Livestock Before Sale}

Auction markets in West Virginia were required by law to

\footnotetext{
${ }^{18}$ Ibid., p. 10.

${ }^{19}$ Unless footnoted otherwise, the material presented under this heading was obtained from personal interview with Joseph C. Emch, State Extension SpecialistAnimal Husbandry, and Noah E. Perry, Chief of the Livestock Section, West Virginia Department of Agriculture.
} 
employ a licensed weighman, a licensed grader, and a licensed auctioneer at every sale. ${ }^{20}$ Weighing facilities were supervised by representatives of the State Department of Agriculture and the State Department of Labor. All official grading, sorting, and classifying was conducted by the State Department of Agriculture with fees for this service being charged to the auctions. The Cooperative Extension Service complemented this service for the duration of the special feeder calf sales in the fall. Feeding and watering facilities were available at all markets. It was believed that these facilities could have been improved.

\section{Sales Room}

The sales room for all auctions consisted of a ring, a booth for the auctioneer and attendants, and seating space for the public. Typically, the sales room was organized as a U-shaped amphitheater, with wooden or concrete stadium-type seats allowing the public an unrestricted view of the ring and auctioneer.

\section{Sale Characteristics}

Regular sales were held once a week at all markets (Appendix Table 1) and commenced between 1 and 2 p.m. on the assigned day. The length of the sale varied considerably with the season, but generally ended about 6 p.m. Generally speaking, there was no rigid order of selling the different classes of livestock. The order of selling was instead left flexible to suit buyers and auction personnel. Bidding characteristics were consistent with normal auction procedures; each consignment or lot being sold on its merits to the highest bidder. Communication between the auctioneer and buyers followed established patterns. Auctions allowed the seller to "pass out" (cancel the sale of his consignment) if the price was not acceptable to him, providing his livestock was not in a co-mingled lot. Buyers were warned of defective consignments with the phrase "sold as is." Major buyer participation at these sales appeared to come from farmers, packers, and order buyers. The relative importance of any one buyer group appeared to vary with the season. However, an accurate appraisal of this variation was not possible. All financial settlements were cleared through the auction office within the time limit designated by p. 10 .

${ }^{20}$ Laws of West Virginia Relating to Agriculture and Veterinarians, op. eit., 
the Packers and Stockyard Act, but usually directly after each sale. ${ }^{21}$

\section{LIVESTOCK AUCTION COSTS}

Data for this study were obtained from the 1967 and 1968 Annual Reports of West Virginia livestock auction markets as submitted to the Commissioner of Agriculture in Charleston. These records contained complete livestock volume data for all of the 20 markets in each of the study years. However, one respondent in 1967 and three respondents in 1968 had omitted the cost section of the State Department of Agriculture questionnaire. (For an example of this questionnaire, see Appendix Table 2).

Data for the two study years (1967-1968) were averaged and classified under the following sub-headings:

1. Labor costs. These include officers and executive salaries, management and supervision salaries, office salaries (clerical), wages, and the auctioneer's salary;

2. Utilities. Include heat and fuel, light and power, water, telephone and telegraph;

3. Investment costs. Include depreciation and depletion of operating equipment, insurance and bonds, taxes, interest, and capital improvement costs;

4. Operating costs. Include repairs and maintenance of buildings, equipment, and land, office supplies (stamps, stationery and other office supplies), feed, transportation and gasoline, market news service, and lease costs;

5. Miscellaneous. Includes yard supplies, veterinary fees, medicines and vaccines, grading fees, death losses, freight charges, donations, bad debts, legal and audit fees, workmen's compensation, subscriptions and dues, and licenses (Table 3).

The largest component of total cost was that of labor (56.1 per cent). Wages were the largest element of the total labor costs, amounting to 40.4 per cent of total labor costs and 22.7 per cent of total cost. It may be recalled that Abrahamsen ${ }^{22}$ found total labor costs to be about 60 per cent of all total costs.

\footnotetext{
${ }^{21}$ Payments must be made before the close of the next business day. United States Department of Agriculture, Packers and Stockyards Act of 1921, as Amended, Packers and Stockyards Administration, U. S. Department of Agriculture (Washington: U. S. Government Printing Office, 1967), p. 37.

${ }^{22}$ Abrahamsen, op. eit., pp. $75-76$.
} 
Investment costs were 21.1 per cent of total cost; operating costs were 11.7 per cent; utilities, 3.5 per cent; and miscellaneous costs, 7.6 per cent.

\section{ESTIMATION OF LIVESTOCK CONVERSION COEFFICIENTS}

Market volume data for the two study years encompassed the major livestock species, under the broad classifications of "cattle," "calves," "hogs," and "sheep and lambs." Records also included details of minor species (horses and mules, chickens, rabbits);

\section{TABLE 3}

COST BREAKDOWN FOR WEST VIRGINIA LIVESTOCK AUCTIONS, AVERAGE DATA FOR 17 FIRMS IN 1967 AND 15 FIRMS IN $1968^{\mathrm{a}}$

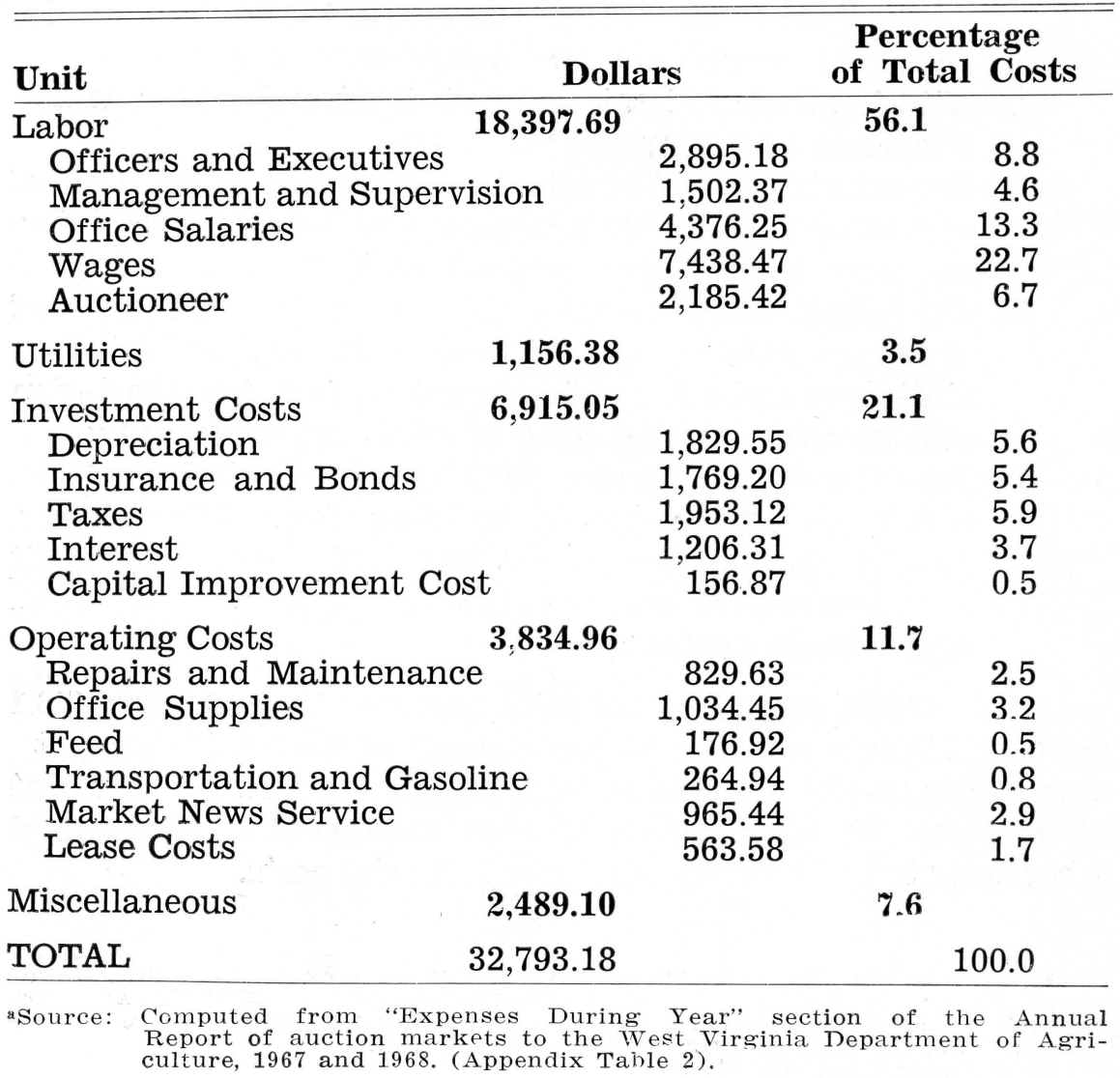


of other agricultural products (eggs, apples, hides); and, of miscellaneous merchandise (farm machinery, domestic appliances). Since the latter items in aggregate constituted a relatively small proportion of total dollar turnover, and in view of the practical difficulties of quantifying such a diverse range of merchandise, only the major livestock species-cattle, calves, hogs, and sheep and lambs-were included in this study (Tables 4 and $5)$. Livestock volume was expressed in terms of the number of head of each species handled by an auction in one year. Total costs were computed directly from the annual state questionnaire to auction markets.

In order to proceed with the cost analysis and in order to develop comparable unit costs for different markets, it was necessary to convert heterogeneous livestock species to common units. One way of accomplishing this would have been to use a con-

\section{TABLE 4}

ANNUAL MARKET COSTS AND LIVESTOCK VOLUME. BY MAJOR SPECIES, FOR 19 WEST VIRGINIA

LIVESTOCK AUCTIONS, $1967^{\mathrm{a}}$

\begin{tabular}{crcrcr}
\hline $\begin{array}{c}\text { Market } \\
\text { Code }\end{array}$ & Cattle & Calves & Hogs & $\begin{array}{c}\text { Sheep \& } \\
\text { Lambs }\end{array}$ & $\begin{array}{c}\text { Total } \\
\text { Costs }\end{array}$ \\
\hline 6701 & 3,437 & 5,791 & 3,268 & 10,649 & $\$ 27,698.34$ \\
6702 & 12,801 & 4,558 & 5,751 & 14,375 & $57,633.90$ \\
6703 & 6,136 & 6,223 & 15,175 & 2,811 & $47,172.32$ \\
6704 & 11,685 & 3,212 & 639 & 694 & $49,294.84$ \\
6705 & 5,733 & 3,220 & 534 & 2,052 & $24,115.11$ \\
6706 & 3,021 & 4,348 & 839 & 2,356 & $33,612.33$ \\
6707 & 1,689 & 634 & 318 & 2,209 & $9,511.70$ \\
6708 & 2,339 & 1,895 & 610 & 605 & $14,755.44$ \\
6709 & 1,025 & 834 & 734 & 2,825 & $10,570.06$ \\
6710 & 2,936 & 1,419 & 331 & 231 & $15,393.90$ \\
6711 & 5,049 & 4,195 & 1,589 & 1,957 & $27,842.56$ \\
6712 & 1,693 & 3,602 & 837 & 1,582 & $17,716.76$ \\
6713 & 1,187 & 2,679 & 459 & 18,837 & $20,253.17$ \\
6714 & 9,730 & 3,951 & 3,780 & 524 & $37,464.60$ \\
6715 & 14,325 & 4,300 & 10,781 & 36,863 & $101,334.25$ \\
6716 & 7,737 & 9,043 & 1,394 & 1,524 & $47,426.77$ \\
6717 & 7,538 & 4,538 & 2,565 & 5,109 & $35,943.56$ \\
6718 & 10,211 & 4,994 & 3,081 & 3,681 & $45,945.28$ \\
6719 & 8,697 & 3005 & 1,378 & 3,338 & $46,889.70$ \\
\hline
\end{tabular}

asource: Derived from the 1967 Annual Reports of Livestock Auction Markets to the Commissioner of Agriculture, West Virginia Department of Agriculture, Charleston. 
ventional livestock unit in which the common animal denominator is based on feed consumption or space requirements. However, such a measure would not necessarily correlate each species with market costs and, therefore, would not contribute to the specific objectives of this analysis. A second alternative would be that of categorizing auctions according to annual dollar turnover. This procedure, while giving a superficial indication of market size, would not facilitate the development of comparable unit costs for different firms. A third alternative would center around the use of a ratio based upon auction market commission fees. However, due to the diversity of tariff schedules between auctions, this measure was also rejected.

It was, therefore, decided to use multiple regression techniques to relate the numbers of individual livestock species (independent variables) to market costs (dependent variable). This method could then be used to derive cost coefficients which were directly applicable to West Virginia conditions. A linear multiple regression model of the form:

TABLE 5

ANNUAL MARKET COSTS AND LIVESTOCK VOLUME, BY MAJOR SPECIES, FOR 17 WEST VIRGINIA

LIVESTOCK AUCTIONS, $1968^{a}$

\begin{tabular}{lrcrcr}
\hline \hline $\begin{array}{c}\text { Market } \\
\text { Code }\end{array}$ & Cattle & Calves & Hogs & $\begin{array}{c}\text { Sheep \& } \\
\text { Lambs }\end{array}$ & $\begin{array}{c}\text { Total } \\
\text { Costs }\end{array}$ \\
\hline 6801 & 3,612 & 6,485 & 2,918 & 10,618 & $\$ 29,551.30$ \\
6802 & 12,638 & 4,653 & 5,903 & 12,231 & $93,502.57$ \\
6803 & 7,200 & 5,691 & 15,526 & 2,164 & $51,354.40$ \\
6804 & 12,144 & 5,092 & 824 & 752 & $53,313.29$ \\
6805 & 3,814 & 1,459 & 385 & 938 & $21,256.55$ \\
6806 & 2,052 & 556 & 265 & 1,710 & $14,418.60$ \\
6807 & 3,199 & 1,672 & 623 & 691 & $17,432.55$ \\
6808 & 1,014 & 812 & 582 & 2,823 & $8,277.92$ \\
6809 & 3,096 & 1,654 & 342 & 162 & $17,600.67$ \\
6810 & 4,566 & 3,731 & 1,223 & 1,901 & $27,984.86$ \\
6811 & 1,657 & 3,613 & 532 & 1,383 & $15,660.75$ \\
6812 & 1,794 & 2,830 & 302 & 19,622 & $20,872.52$ \\
6813 & 9,680 & 3.691 & 4,522 & 353 & $37,238.00$ \\
6814 & 7,046 & 8,234 & 1,053 & 957 & $46,957.34$ \\
6815 & 6,381 & 4,080 & 2,217 & 4,577 & $38,258.60$ \\
6816 & 11,415 & 5,107 & 3,276 & 3.363 & $47,636.26$ \\
6817 & 10,143 & 3,115 & 1,210 & 3,611 & $50,862.16$ \\
\hline
\end{tabular}

aSource: Derived from the 1968 Annual Reports of Livestock Auction Markets to the Commissioner of Agriculture, West Virginia Department of Agriculture, Charleston. 


$$
\mathrm{Y}=\mathrm{A}+\mathrm{b}_{1} \mathrm{X}_{1}+\mathrm{b}_{2} \mathrm{X}_{2}+\mathrm{b}_{3} \mathrm{X}_{3}+\mathrm{b}_{4} \mathrm{X}_{4}
$$

was used where,

$\mathrm{Y}=$ Total costs per livestock auction per year;

$\mathrm{A}=\mathrm{A}$ positive intercept on the $\mathrm{Y}$ axis representing market costs when sales volume approaches zero, in other words, fixed market costs;

$\mathbf{X}_{1}=$ The number of cattle handled in a year;

$\mathbf{X}_{2}=$ The number of calves handled in a year;

$\mathbf{X}_{3}=$ The number of hogs handled in a year;

$\mathbf{X}_{t}=$ The number of sheep and lambs handled in a year.

The partial regression coefficients obtained from this model implicitly recognize the marginal market cost incident upon the sale of one head of a particular species. Thus, the results can be directly converted into coefficients for converting livestock species to common units, or "livestock marketing units."

Combined data from Tables 4 and 5, representing 36 observations of a two-year population of 40 , were used to develop the model. ${ }^{24}$ A stepwise linear regression program was used (for analysis of variance of the multiple correlation coefficient see Appendix Table 4$)^{25}$, which yielded the following equation:

$$
\begin{array}{r}
\mathrm{Y}=1790.32+3.681 \mathrm{X}_{1}+1.289 \mathrm{X}_{2}+0.876 \mathrm{X}_{3}+0.769 \mathrm{X}_{4} \\
(0.349)^{* *}(0.679) \\
(0.371) * \mathrm{C}^{2}(0.173) * * \\
\mathrm{R}^{2}=.90
\end{array}
$$

Standard errors of the estimates of the multiple regression equation are printed in parentheses below the partial regression coefficients. A double asterisk denotes significance at the .01 level; a single asterisk denotes significance at the .05 , but not at the .01 level. The $\mathrm{R}^{2}$ value of .90 indicates that the four variables, $\mathrm{X}_{1}, \mathrm{X}_{2}, \mathrm{X}_{3}$, and $\mathrm{X}_{4}$, accounted for 90 per cent of the variability around $Y$. The equation suggests that for each additional head of cattle marketed, total costs would increase by $\$ 3.68$. For each additional calf, the increase would be $\$ 1.29$; for each hog, $\$ .88$; and for each sheep or lamb, \$.77.

${ }^{23}$ A "livestock marketing unit" (L. M. U.) was construed in this study to mean an integer constant which relates the number of head of individual species, equivalent in terms of market cost, to a base unit of one represented by "cattle."

${ }^{24} \mathrm{~A}$ combination of the data for two years would reduce inter-year variations in the cost accounts. A statistical comparison of the means of the 1967 and 1968 data is given in Appendix Table 3.

${ }^{25}$ Computer program used was University of California, Biomedical Computer Program, BMDO2R, "Stepwise Regression." For a description of this program, see W. J. Dixon (ed.), Biomedical Computer Programs, University of California Publications in Automatic Computation No. 2 (second edition; Berkeley and Los Angeles, University of California Press, 1968), pp. 233-257. 


\section{COMPARISON OF REGRESSION COEFFICIENTS WITH ACTUAL AUCTION FEES}

Public livestock markets in West Virginia were required under the provisions of the Packers and Stockyards Act to post approved "tariff sheets," or schedules of charges relating to their market activities. Commission charges were levied at most auction markets on a discriminate basis against specified livestock categories classified by weight, sex, and sometimes lot size (with small lots incurring a penalty). In some cases, these commissions were incremented by a yardage fee, normally 1.0 or 1.5 per cent of gross sales, whereas other markets listed fees inclusive of commissions and yardage. Feed charges were levied by most markets at cost F.O.B. the stockyards, though some did add a percentage or absolute amount to this initial charge. Fees for veterinary inspections and additional services complemented the schedule.

Since the fee schedules varied for different markets in the State, both in the method of classifying livestock categories and in the magnitude of the fees, it was not possible to devise a truly representative average schedule for all markets. Nevertheless, an example of part of a fairly typical tariff sheet of a West Virginia livestock auction market is reproduced in Appendix Table 5. The fees presented in this tariff sheet, as well as could be appraised, appeared to compare favorably with the regression coefficients derived in the previous section.

This comparison, therefore, appeared to support the use of livestock conversion coefficients derived from regression techniques. Livestock marketing units were computed from the partial regression coefficients by relating the number of head of the various species equivalent, in terms of total market costs, to one "cattle"-a ratio of 1 cattle: 3 calves: 4 hogs: 5 sheep and lambs.

\section{ANALYSIS OF COST AND VOLUME DATA}

Livestock marketing units (LMU's) derived in the proceding chapter were used to rank auctions on a common size basis and to compute total costs per LMU for West Virginia livestock auctions. Results, tabulated in Table 6 , exhibited a range in market size of over 23,000 LMU's for 19 firms in 1967, and over 12,500 LMU's for 16 firms in 1968. ${ }^{26}$ The scatter of total costs per LMU for each of the two study years generally declined as firm size increased.

\footnotetext{
${ }^{26}$ Cost data for the largest firm (28,710 LMU's) in 1968 were not available. The second largest firm in 1968 was omitted from all cost analyses in the study due to a bias in the data resulting from participation in non-market business operations in that year.
} 
TABLE 6

SIZE RANGE AND AVERAGE TOTAL COSTS FOR WEST VIRGINIA AUCTION MARKETS, RANKED IN ASCENDING ORDER OF LIVESTOCK MARKETING UNITS, 19 FIRMS IN 1967, 16 FIRMS IN 1968

\begin{tabular}{rrrrrr}
\hline \hline & $\mathbf{1 9 6 7}$ & & & $\mathbf{1 9 6 8}^{\mathrm{b}}$ \\
\cline { 1 - 2 } \cline { 5 - 5 } LMU & $\begin{array}{c}\text { Cost per } \\
\text { LMU }\end{array}$ & & LMU & $\begin{array}{c}\text { Cost per } \\
\text { LMU }\end{array}$ \\
\hline 2,052 & $\$ 5.15$ & & 1,995 & $\$ 4.15$ \\
2,422 & 3.93 & & 2,646 & 5.45 \\
3,244 & 4.55 & & 3,271 & 4.79 \\
3,419 & 5.18 & & 3,765 & 4.67 \\
3,538 & 4.35 & & 4,050 & 4.30 \\
5,151 & 6.52 & & 4,584 & 4.64 \\
5,962 & 3.40 & & 6,496 & 4.31 \\
7,236 & 3.85 & & 6,737 & 3.10 \\
7,350 & 3.28 & & 8,627 & 3.43 \\
8,314 & 3.33 & & 9,211 & 4.15 \\
10,711 & 4.38 & & 10,249 & 4.58 \\
10,714 & 3.35 & & 12,111 & 3.07 \\
11,405 & 3.16 & & 12,206 & 4.17 \\
12,097 & 3.10 & & 13,411 & 3.83 \\
12,566 & 3.75 & & 14,198 & 3.75 \\
13,054 & 3.78 & & 14,609 & 3.26 \\
13,382 & 3.43 & & & \\
18,633 & 3.09 & & & \\
25,326 & 4.00 & & & \\
\hline
\end{tabular}

aSource: Derived from data in Tables 4 and 5.

'Cost data for the largest firm (28,710 LMU's) in 1968 were not available. The second largest firm in 1968 was omitted from all cost analyses in the study due to a bias in the data resulting from participation in non-market business operations in that year.

\section{SEASONAL VARIATIONS IN LIVESTOCK MARKETING}

The problem of unused capacity is commonly encountered in livestock marketing. Seasonal variations in the numbers of various species handled by West Virginia auctions were evident in the monthly marketing data presented in Table 7. The peak sales period for the ruminants (cattle, calves, and sheep and lambs) occurred in the months of September, October, and November. By contrast, hogs maintained a relatively even market flow throughout the year. Data in Table 7 were converted to a monthly index of the two-year annual mean (equivalent to a base of 100) for each species and for total LMU's handled (Table 8). Results are illustrated graphically in Figure 1. The greatest absolute annual 


\section{TABLE 7}

MONTHLY VARIATIONS IN VOLUME OF MARKETINGS, BY NUMBERS OF MAJOR SPECIES, WEST VIRGINIA LIVESTOCK AUCTIONS, 1967 AND 1968

\begin{tabular}{|c|c|c|c|c|c|c|c|c|}
\hline & \multicolumn{2}{|c|}{ Cattle } & \multicolumn{2}{|c|}{ Calves } & \multicolumn{2}{|c|}{ Hogs } & \multicolumn{2}{|c|}{$\begin{array}{c}\text { Sheep \& } \\
\text { Lambs }\end{array}$} \\
\hline & 1967 & 1968 & $196 \%$ & 1968 & $196 \%$ & 1968 & $196 \%$ & 1968 \\
\hline January & 5,722 & 4,331 & 3,605 & 3,106 & 4,163 & 4,331 & 3,246 & 3,027 \\
\hline February & 3,046 & 3,384 & 2,383 & 2,472 & 3,545 & 4,101 & 956 & 1,870 \\
\hline March & 4,122 & 5,225 & 3,487 & 3,223 & 4,506 & 5,076 & 1,682 & 1,704 \\
\hline April & 13,651 & 13,549 & 4,092 & 3,631 & 4,669 & 4,746 & 1,106 & 1,514 \\
\hline May & 5,820 & 5,567 & 4,304 & 3,614 & 5,724 & 4,832 & 1,985 & 1,886 \\
\hline June & 4,747 & 5,421 & 4,823 & 4,321 & 5,266 & 5,043 & 7,224 & 6,338 \\
\hline July & 5,893 & 6,415 & 5,136 & 4923 & 4,613 & 5,048 & 12,654 & 12,336 \\
\hline August & 7,388 & 8,258 & 5,411 & 4,732 & 3,473 & 3,594 & 18,145 & 15,793 \\
\hline September & 14,645 & 18,001 & 9,635 & 6,973 & 4,521 & 3,644 & 21,653 & 21,677 \\
\hline October & 30,699 & 28,976 & 17,795 & 23,210 & 4,677 & 4,547 & 21,719 & 24,960 \\
\hline November & 17,724 & 20,318 & 8,358 & 7,870 & 5,725 & 5,758 & 17,057 & 13,015 \\
\hline December & 5,392 & 5,111 & 3,017 & 3,076 & 3,998 & 4,324 & 5,004 & 4,356 \\
\hline \multicolumn{9}{|l|}{ Annual } \\
\hline Average & 9,904 & 10,380 & 6,004 & 5,929 & 4,573 & 4,587 & 9,369 & 9,040 \\
\hline \multicolumn{9}{|l|}{ Average for } \\
\hline
\end{tabular}

asource: Taken from the Annual Reports of Livestock Auction Markets to the West Virginia Department of Agriculture, 1967 and 1968. Includes

bRounded. total market population. 
variation in numbers occurred for cattle. Calves, however, experienced the widest percentage fluctuation, reflecting the increased sales momentum of the well publicized special feedercalf sales in October.

In terms of total LMU's, the index of monthly variation in marketings indicated that West Virginia auctions operated below the annual mean market volume for eight months in the year. The mean market volume (Index $=100$ ) represented a mere 36 per cent of the maximum October market volume, which suggests considerable under-utilization of plant capacity on an annual basis. This observation does not take into consideration the week-to-week under-utilization of plant capacity resulting from the once a week sale characteristics of auctions in the State.

\section{STRATIFIED UNIT COST COMPARISONS}

Market data were divided into three size groups for purposes of investigating unit cost components. The smallest size group encompassed all markets handling less than 6,000 LMU's per year;

\section{TABLE 8}

MONTHLY INDEX OF MARKETING VOLUME, BY MAJOR SPECIES AND LIVESTOCK MARKETING UNITS, WEST VIRGINIA LIVESTOCK AUCTIONS, 1967 AND $1968^{\mathrm{a}}$

\begin{tabular}{lccccc}
\hline \hline & Cattle & Calves & Hogs & $\begin{array}{c}\text { Sheep \& } \\
\text { Lambs }\end{array}$ & LIMU $^{\text {b }}$ \\
\hline January & 50 & 56 & 93 & 34 & 52 \\
February & 32 & 41 & 83 & 15 & 35 \\
March & 46 & 56 & 105 & 18 & 48 \\
April & 134 & 65 & 103 & 14 & 108 \\
May & 56 & 66 & 115 & 21 & 58 \\
June & 50 & 77 & 113 & 74 & 61 \\
July & 61 & 84 & 105 & 136 & 76 \\
August & 77 & 85 & 77 & 184 & $\mathbf{9 1}$ \\
September & 161 & 139 & 89 & 235 & 162 \\
October & 294 & 344 & 101 & 254 & $\mathbf{2 8 1}$ \\
November & 188 & 135 & 125 & 163 & $\mathbf{2 5 1}$ \\
December & 52 & 51 & $\mathbf{9 1}$ & 51 & 55 \\
\hline
\end{tabular}

'Source: Computed from Table 7. Monthly indices represent percentage variation from the two-year annual mean $(=100)$. Rounded two-year annual means from Table 7 were: for cattle, 10,142, for calves, 5,967; for hogs, 4,580; and for sheep and lambs, 9,205.

bMonthly indices of LMU's were obtained by converting two-year average numbers for each species into LMU's. Total monthîy LMU's were expressed as indices of the two-year annual mean LiMU's $(15,117)$ represented by a base of 100 . 
the intermediate group ranged from 6,000 LMU's to 11,999 LMU's; and the largest size group included all firms handling over 12,000 LMU's. Cost data for individual components of total costs were used to compute costs per livestock marketing unit and results were averaged for each of the size groups specified ${ }^{2^{7}}$ Data were obtained from records of 19 firms in 1967 and 16 firms in 1968.

Group total costs per livestock marketing unit, for a total of 35 firms in 1967 and 1968, were $\$ 4.09$ (Table 9). For the small firms (below 6,000 LMU's per annum), group average total costs were $\$ 4.70$; for intermediate firms $(6,000-11,999$ LMU's per annum). $\$ 3.83$; and for the largest West Virginia auction firms $(12,000$ LMU's and over), \$3.59. This decline in unit costs associated with an increase in firm size conforms to the economic theory of the firm and is reflected in most of the individual cost components shown in Table 9.

\section{STATISTICAL ESTIMATES OF COST FUNCTIONS}

The stratified unit-cost relationship was expressed graphically by using least squares techniques to fit the appropriate unit cost functions to the cost and volume data. Data for a total of 35 firms in the two study years were used. In order to reduce interfirm cost deviations, data were grouped into eight combined size categories as shown in Table 10. A stepwise linear regression program was employed to estimate the four regression equations postulated below:

$$
\begin{aligned}
& \mathrm{Y}_{\mathrm{t}}=\mathrm{A}+\mathrm{b}_{1} \mathrm{X}_{1}+\mathrm{b}_{2} \mathrm{X}_{2} \\
& \mathrm{Y}_{\mathrm{t}}=\mathrm{A}+\mathrm{b}_{1}\left(\frac{1}{\mathrm{X}_{1}}\right) \\
& \log \mathrm{Y}_{\mathrm{t}}=\mathrm{A}+\mathrm{b}_{1} \log \mathrm{X}_{1} \\
& \mathrm{Y}_{\mathrm{t}}=\mathrm{A}+\mathrm{b}_{1}\left(\frac{1}{\mathrm{X}_{1}}\right)+\mathrm{b}_{2}\left(\frac{1}{\mathrm{X}_{2}}\right)
\end{aligned}
$$

where,

$\mathrm{Y}_{\mathrm{t}}=$ Total cost per livestock marketing unit in cents;

$\mathrm{A}=$ Constant term;

$\mathrm{X}_{1}=$ Hundreds of livestock marketing units handled in a year;

$\mathbf{X}_{2}=$ Squared value of $\mathbf{X}_{1}$.

${ }^{2 \pi}$ Computer program used was University of California, Biomedical Computer Program, BMDO7D, "Description of Strata with Histograms." For a description of this program, see W. J. Dixon (ed.), Biomedical Computer Programs, University of California Publications in Automatic Computation No. 2 (second edition; Berkeley and Los Angeles, University of California Press, 1968), pp. 95-108. 


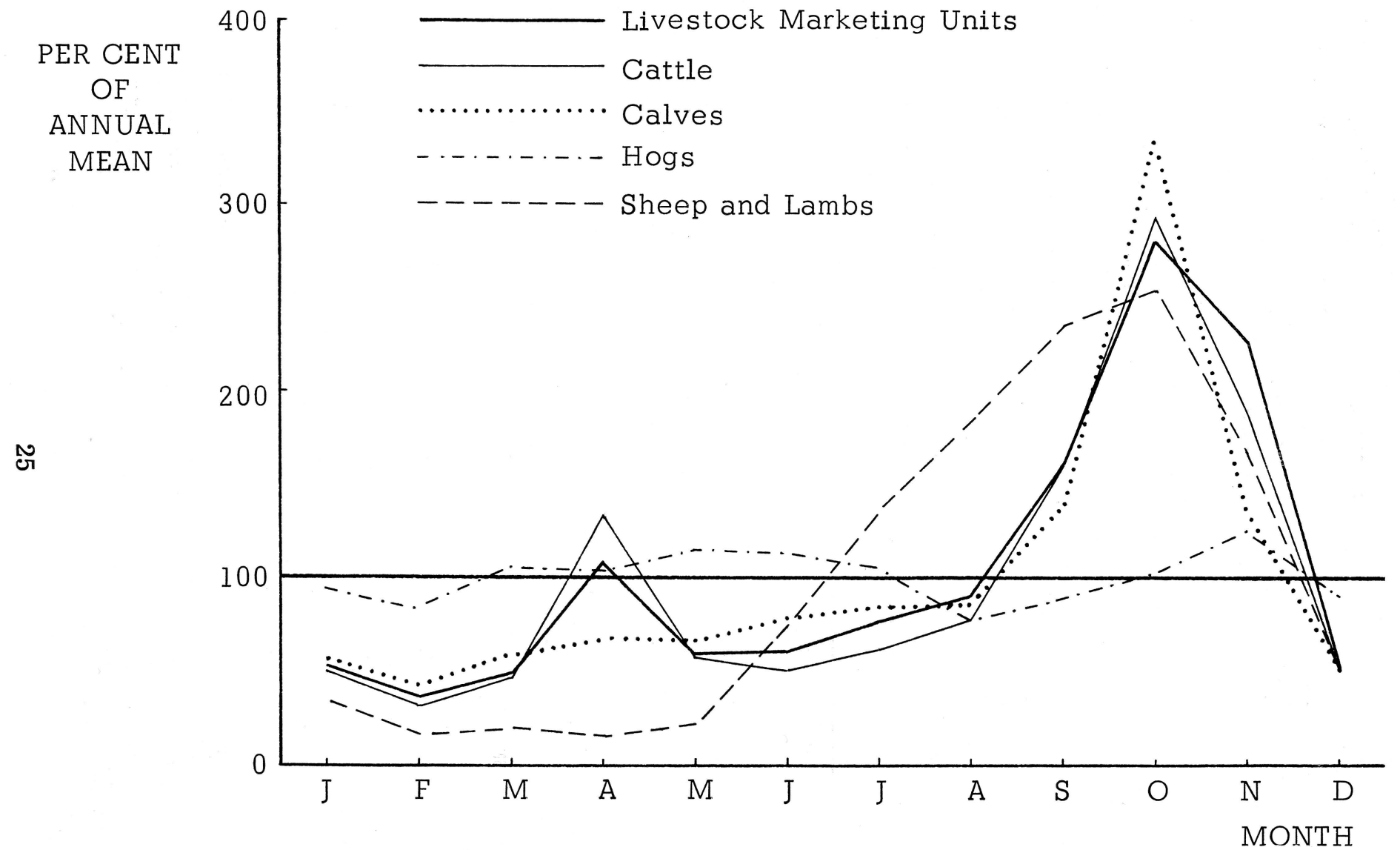

Figure 1. Monthly index of marketing volume (two-year annual mean $=100$ ), by major species and livestock marketing units, West Virginia livestock auctions, 1967 and 1968 (From data in Tables 7 and 8). 
TABLE 9

MEAN COSTS PER LIVESTOCK MARKETING UNIT FOR MAJOR COMPONENTS BY SPECIFIED FIRM

SIZE GROUPS, 19 FIRMS IN 1967,

16 FIRMS IN $1968^{a}$

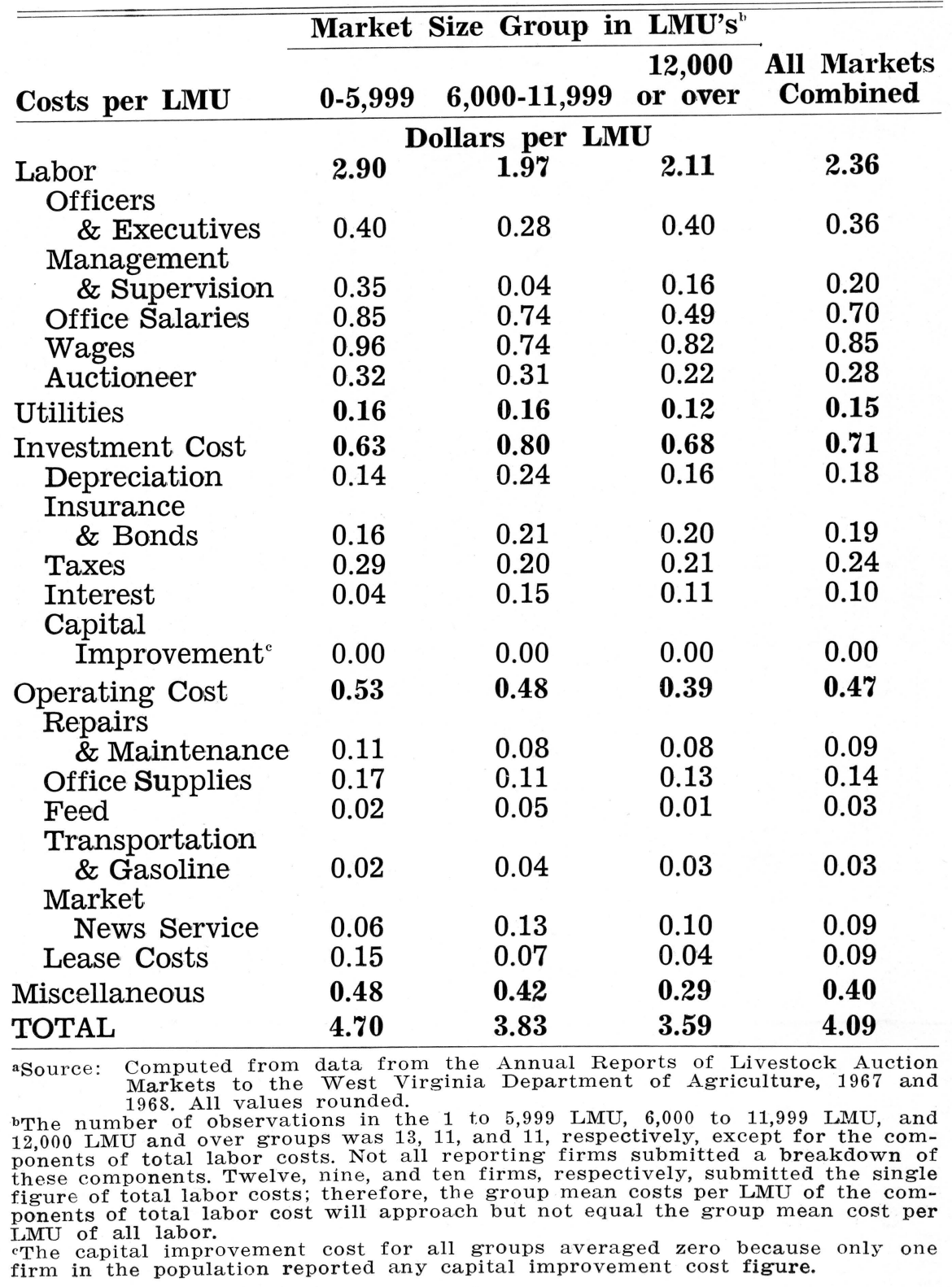


The quadratic equation (1) can be used to describe a cost function which is consistent with economic theory; that is, one which decreases at a decreasing rate, reaches a minimum, and then increases at an increasing rate. Equations (2) and (3) have asymptotic characteristics; that is, they tend to flatten out as they approach zero, but never reverse their slope. Equation (4), which incorporates the reciprocals of the independent variables of the quadratic equation (1), is an extension of equation (2).

The following significant equations (see appropriate analyses of variance of the multiple correlation coefficient in Appendix Table 6), were yielded, where $\mathrm{Y}_{\mathrm{t}}$ refers to the aggregate average total cost function:

(1)

$$
\begin{array}{r}
\mathrm{Y}_{\mathrm{t}}=509.72-\underset{1.8484 \mathrm{X}_{1}+}{ }+0.0054 \mathrm{X}_{2} \\
(0.6357) * \\
(0.0026) \\
\mathrm{R}_{2}=.75
\end{array}
$$

$\stackrel{(2)}{\mathrm{Y}_{\mathrm{t}}=349.28}+\underset{(798.54)}{3 * *} \stackrel{1}{\mathrm{X}_{1}}$

$$
R_{2}=.72
$$

(3)

$\log \mathrm{Y}_{\mathrm{t}}=2.8562-0.1355 \log \mathrm{X}_{1}$

$$
\mathrm{R}_{2}=.70
$$

$\mathrm{Y}_{\mathrm{t}}=321.55+6747.02\left(\frac{1}{\mathrm{X}_{1}}\right)-75192.81\left(\frac{1}{\mathrm{X}_{2}}\right)$

$(3689.13)$

$$
\mathrm{R}_{2}=.77
$$

Again, standard errors of estimate are in parentheses below the corresponding partial regression coefficients. A double asterisk denotes significance at the .01 level; a single asterisk denotes significance at the .05 level.

The functions appropriate to these equations were plotted on the arithmetic scale graph in Figure 2. Equations (2), (3), and (4) appeared to conform well to economic theory. Other livestock auction cost studies have indicated that diseconomies of size are not likely to occur over the size range discussed in this paper, and, therefore, the quadratic equation (1) could perhaps have been 
TABLE 10

COST DATA FOR A DISTRIBUTION OF WEST VIRGINIA

LIVESTOCK AUCTIONS INTO COMBINED

SIZE CATEGORIES, 19 FIRMS IN 1967, 16 FIRMS IN $1968^{\mathrm{a}}$

\begin{tabular}{cccc}
\hline $\begin{array}{c}\text { Group Interval } \\
\text { (LMU's) }\end{array}$ & $\begin{array}{c}\text { Number } \\
\text { of Firms }\end{array}$ & $\begin{array}{c}\text { Group Average Group Average } \\
\text { Size (LMU's) }\end{array}$ & $\begin{array}{c}\text { Grotal Costs } \\
\text { Thy }\end{array}$ \\
\hline $0-2,999$ & 4 & 2,279 & $\$ 10,694.57$ \\
$3,000-4,999$ & 7 & 3,696 & $17,116.66$ \\
$5,000-6,999$ & 4 & 6,087 & $25,680.72$ \\
$7,000-8,999$ & 4 & 7,882 & $27,301.83$ \\
$9,000-10,999$ & 4 & 10,221 & $42,012.30$ \\
$11,000-12,999$ & 5 & 12,077 & $44,032.77$ \\
$13,000-14,999$ & 5 & 13,731 & $49,508.81$ \\
15,000 and over & 2 & 21,980 & $79,484.08$ \\
\hline
\end{tabular}

asource: Derived from data in Tables 4 and 5 .

excluded. ${ }^{2 s}$ The curves in Figure 2 represent the costs per livestock marketing unit associated with markets of different sizes. Since they do not necessarily imply full capacity utilization, they do not conform strictly to the theoretical concept of the long-run average cost curve. The true long-run average cost curve would lie somewhere below the aggregate average total cost curve depicted in Figure 2, with its exact location depending on percentage capacity utilization of various sized plants. Nevertheless, the unit cost-size relationship yielded in this study has direct relevance to West Virginia livestock auctions. The curves in Figure 2 exhibit considerable unit cost advantages over their range. The most marked decline in unit costs occurred in markets which handled up to 6,000 LMU's per year. Beyond this point, cost economies were not as great, though unit cost gains for markets in the 6,000 to $24,000 \mathrm{LMU}$ range were in the order of 50 cents per LMU (approximately 12 per cent) for total unit costs.

${ }^{28}$ Lindberg and Judge demonstrated declining average costs over a market size range of 70,000 animal units (one animal unit equivalent to one horse, one head of cattle over $400 \mathrm{lbs}$, two calves $400 \mathrm{lbs}$. or less, two hogs, five sheep). R. C. Lindberg and G. G. Judge, Estimated Cost Functions for oklahoma Livestock Auctions, Oklahoma Agricultural Experiment Station, Bulletin B-520 (Oklahoma State University, January, 1958), p. 23. Wootan and McNeely demonstrated cost economies over a market size range of up to over 190,000 animal units (one animal unit equivalent to one head of cattle, one hog, six sheep). Charles V. Wootan and John G. McNeely, Factors Affecting Auction Market operating Costs, Texas Agricultural Experiment Station, B-1056 (College Station, October, 1966), p. 28. 


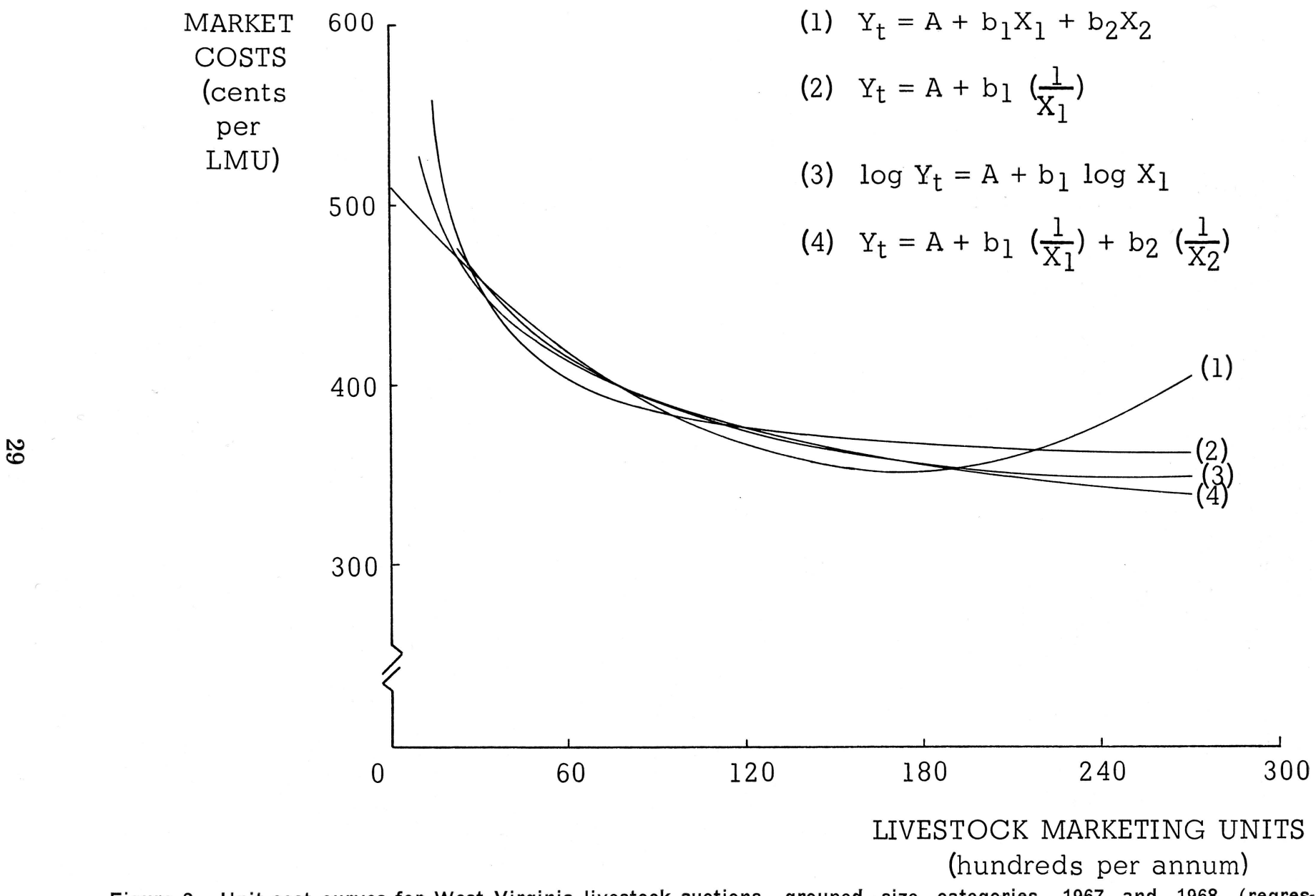

Figure 2. Unit cost curves for West Virginia livestock auctions, grouped size categories, 1967 and 1968 (regression equations computed from data in Table 10). 
APPENDIX TABLE 1

\section{WEST VIRGINIA LIVESTOCK AUCTION \\ MARKETS, LOCATIONS AND \\ SCHEDULED SALE DATES, 1968}

Name and Location of Market

Alderson Livestock Market

Alderson

Bluegrass Market, Inc.

North Caldwell

Blue Ridge Livestock Sales, Inc.

Charles Town

Bridgeport Stockyards, Inc.

Bridgeport

Buckhannon Stockyards

Buckhannon

Evans Stockyards, Inc.

Elkins

Gassaway Livestock Market, Inc. Gassaway

Jackson County Livestock Market, Inc. Ripley

Mannington Livestock Sales Co., Inc. Mannington

Morgantown Livestock Sales, Inc. Morgantown

Moundsville Livestock Auction Co. Moundsville

New River Livestock Market Beckley

Ohio County Livestock Auction, Inc. West Alexander, $\mathrm{Pa}$.

Pocahontas Producers Co-Op. Assn. Marlinton

Point Pleasant Livestock Co. Point Pleasant

South Branch Stockyards, Inc. Moorefield

Spencer Livestock Exchange Co. Spencer

Terra Alta Stockyards, Inc.

Terra Alta

Union Livestock Sales Co., Inc.

Parkersburg

Weston Livestock Sales Co., Inc.

Weston
Sale Day and Time

Monday 1:30 P.M.

Saturday 1:00 P.M.

Monday 1:30 P.M.

Monday 1:30 P.M.

Wednesday 1:30 P.M.

Thursday 1:30 P.M.

Monday 1:30 P.M.

Thursday 1:30 P.M.

Saturday 2:00 P.M.

Wednesday 1:00 P.M.

Monday 2:00 P.M.

Wednesday 1:00 P.M.

Wednesday 2:30 P.M.

Tuesday 1:30 P.M.

Saturday 1:00 P.M.

Wednesday 1:30 P.M.

Friday 1:00 P.M.

Friday 1:30 P.M.

Saturday 1:00 P.M.

Tuesday 1:00 P.M.

aSource: J. Howard Myers (ed.), West Virginia Blue Book (Charleston: Jarrett Printing Company, 1968), LII, p. 891. 


\section{APPENDIX TABLE 2}

REPLICA OF THE ANNUAL REPORT OF LIVESTOCK AUCTION MARKETS TO THE WEST VIRGINIA DEPARTMENT OF

AGRICULTURE, 1967 AND 1968

\section{Expenses During Year

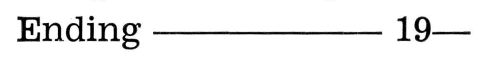

1. Salaries.

Officers and executives.

Other office salaries.

Management and supervision.

Auctioneer.

2. Wages paid.

Operation.

Maintenance.

3. Stamps, stationery, and other office supplies.

4. Feed.

5. Transportation.

6. Heat and fuel.

7. Gasoline.

8. Light and power.

9. Water.

10. Telephone.

11. Telegraph.

12. Market news service.

13. Depreciation and depletion of operation equipment.

14. Taxes.

15. Interest.

16. Insurance and bonds.

17. Repairs on operating equipment.

18. Repairs on building and land.

19. Cost of capital improvement.

20. Payments on notes and mortgages. ${ }^{a}$

21. Cost of leases.

22. Other cost. (list separately)

TOTAL MARKET EXPENSES

asince this item is not an expense, it was omitted from the analysis. 


\section{APPENDIX TABLE 3}

TEST OF THE DIFFERENCE BETWEEN THE MEANS OF THE 1967 AND 1968 STUDY DATA

\begin{tabular}{lccrrr}
\hline \hline & Cattle & Calves & Hogs & $\begin{array}{c}\text { Sheep and } \\
\text { Lambs }\end{array}$ & $\begin{array}{c}\text { Total } \\
\text { Market Costs } \\
\text { per Annum }\end{array}$ \\
\hline \hline Annual Mean 1967 & $6,156.26$ & $3,733.68$ & $2,845.42$ & $5,906.42$ & $\$ 35,293.37$ \\
Annual Mean 1968 & $5,967.70$ & $3,675.00$ & $2,453.12$ & $3,993.59$ & $34,833.99$ \\
Difference & 188.56 & 58.68 & 392.30 & $1,913.83$ & 459.38 \\
Standard Error & & & & & \\
$\quad$ of Difference & $1,362.51$ & 681.99 & $1,281.51$ & $2,500.83$ & $1,163.23$ \\
t-value* & 0.138 & 0.086 & 0.306 & 0.765 & 0.064 \\
\hline \multirow{N}{*}{ *all values insignificant at the } & 05 & & &
\end{tabular}

\section{APPENDIX TABLE 4}

ANALYSIS OF VARIANCE OF REGRESSION OF TOTAL MARKET COSTS ON NUMBERS OF MAJOR LIVESTOCK SPECIES HANDLED PER YEAR

\begin{tabular}{lcccc}
\hline \hline \multicolumn{4}{c}{$\mathrm{Y}=1790.32+3.681 \mathrm{X}_{1}+1.289 \mathrm{X}_{2}+0.876 \mathrm{X}_{3}+0.769 \mathrm{X}_{4}$} \\
\hline Source of Variation & $\begin{array}{c}\text { Degrees of } \\
\text { Freedom }\end{array}$ & Sum of Squares & Mean Square & F Ratio \\
\hline Due to Regression & 4 & $14,110,064,640$ & $3,527,516,160$ & $70.70 * *$ \\
Deviation from Regression & 31 & $1,544,757,248$ & $49,830,864$ & \\
\hline
\end{tabular}

**Denotes significance at the $1 \%$ level. 


\section{APPENDIX TABLE 5}

\section{REPLICA OF PART OF A TARIFF SHEET FOR A}

WEST VIRGINIA LIVESTOCK AUCTION ${ }^{\mathrm{a}}$

\section{SELLING COMMISSION AND YARDAGE}

\section{A. Cattle:}

1. Steers, Heifers, \& Bulls, 300 to 499 lbs.

$\$ 2.30$ per head

2. Steers, Heifers \& Cows, 600 to 699 lbs.

$\$ 3.00$ per head

3. Steers, Heifers, \& Cows, 700 and over

4. Cows \& Calves selling together

$\$ 3.25$ per head

$\$ 4.25$ per unit

B. Bulls:

1. $500 \mathrm{lbs}$. to $599 \mathrm{lbs}$.

$\$ 3.00$ per head

2. 600 to $799 \mathrm{lbs}$.

$\$ 3.25$ per head

3. $800 \mathrm{lbs}$. and over

$\$ 4.50$ per head

C. Calves:

1. Calves weighing under $300 \mathrm{lbs}$.

2. Baby calves

$\$ 1.75$ per head

$\$ 1.10$ per head

D. Hogs:

1. Barrows \& Gilts (sold by weight)

$\$ 1.00$ per head

2. Pigs \& Shoats (100 lbs. or less)

$\$ .75$ per head

3. Boars (weighing over $250 \mathrm{lbs}$.)

$\$ 2.00$ per head

4. Sows and Pigs selling together

$\$ 3.00$ per unit

E. Sheep and Goats:

1. One or more lambs, sheep, and goats $\$ .60$ per head

2. Bucks

$\$ 1.10$ per head

asource: Taken directly from a West Virginia auction tariff sheet (effective 1967). Excludes commission and yardage for horses, ponies, and mules. Excludes details of additional fees (sheep dipping, feed, and weighing). 
APPENDIX TABLE 6

ANALYSIS OF VARIANCE OF REGRESSION OF COST PER LMU ON LMU'S HANDLED PER YEAR (WITH TRANSFORMATION OF DATA) ${ }^{a}$

\begin{tabular}{|c|c|c|c|c|}
\hline \multicolumn{4}{|c|}{$\mathrm{Y}_{\mathrm{t}}=509.72-1.8484 \mathrm{X}_{1}+0.0054 \mathrm{X}_{2}$} & \multirow[b]{2}{*}{ F Ratio } \\
\hline Source of Variation & $\begin{array}{l}\text { egrees of } \\
\text { Freedom }\end{array}$ & Sum of Squares & Mean Square & \\
\hline $\begin{array}{l}\text { Due to Regression } \\
\text { Deviation from Regression }\end{array}$ & $\begin{array}{l}2 \\
5\end{array}$ & $\begin{array}{r}12,395.566 \\
4,045.285 \\
\end{array}$ & $\begin{array}{r}6,197.781 \\
809.057\end{array}$ & $7.661^{*}$ \\
\hline \multicolumn{5}{|c|}{$\mathrm{Y}_{\mathrm{t}}=349.28+3,114.50\left(\frac{1}{\mathrm{X}_{1}}\right)$} \\
\hline Source of Variation & $\begin{array}{l}\text { egrees of } \\
\text { Freedom }\end{array}$ & Sum of Squares & Mean Square & F Ratio \\
\hline $\begin{array}{l}\text { Due to Regression } \\
\text { Deviation from Regression }\end{array}$ & $\begin{array}{l}1 \\
6\end{array}$ & $\begin{array}{r}11,790.379 \\
4,650.473\end{array}$ & $\begin{array}{r}11,790.379 \\
775.079\end{array}$ & $15.212 * *$ \\
\hline \multicolumn{5}{|c|}{$\log \mathrm{Y}_{\mathrm{t}}=2.8562-0.1355 \log \mathrm{X}_{1}$} \\
\hline Source of Variation & $\begin{array}{l}\text { egrees of } \\
\text { Freedom }\end{array}$ & Sum of Squares & Mean Square & F Ratio \\
\hline $\begin{array}{l}\text { Due to Regression } \\
\text { Deviation from Regression }\end{array}$ & $\begin{array}{l}1 \\
6\end{array}$ & $\begin{array}{l}0.013 \\
0.006\end{array}$ & $\begin{array}{l}0.013 \\
0.001\end{array}$ & $13.753 * *$ \\
\hline \multicolumn{5}{|c|}{$\mathrm{Y}_{\mathrm{t}}=321.55+6747.02\left(\frac{1}{\mathrm{X}_{1}}\right)-75192.81\left(\frac{1}{\mathrm{X}_{2}}\right)$} \\
\hline Source of Variation & $\begin{array}{l}\text { Degrees of } \\
\text { Freedom }\end{array}$ & Sum of Squares & Mean Square & F Ratio \\
\hline $\begin{array}{l}\text { Due to Regression } \\
\text { Deviation of Regression }\end{array}$ & $\begin{array}{l}2 \\
5\end{array}$ & $\begin{array}{r}12,576.445 \\
3,861.405\end{array}$ & $\begin{array}{r}6,288.223 \\
772.881\end{array}$ & $8.136^{*}$ \\
\hline
\end{tabular}

${ }^{a} Y_{t}$ refers to total cost per livestock marketing unit.

**Denotes significance at the $1 \%$ level.

*Denotes significance at the $5 \%$ level. 


\section{BIBLIOGRAPHY}

Abrahamsen, M. A. Livestock Marketing Agencies in West Virginia. West Virginia Agricultural Experiment Station, Bulletin 312. Morgantown: 1943.

Dixon, W. J. (ed.). Biomedical Computer Programs. University of California Publications in Automatic Computation No. 2. Second edition. Berkeley and Los Angeles: University of California Press, 1968.

Hutson, W. S. Livestock Marketing Practices of West Virginia Farmers. West Virginia Agricultural Experiment Station, Bulletin 384. Morgantown: 1955.

Leftwich, Richard H. The Price System and Resource Allocation. Third edition. New York: Holt, Rinehart, and Winton, 1966.

Lindberg, R. C., and C. G. Judge. Estimated Cost Functions for Oklahoma Livestock Auctions. Oklahoma Agricultural Experiment Station, Bulletin B-502. Oklahoma State University, 1958.

Myers, J. Howard (ed.), West Virginia Bluebook, Charleston: Jarrett Printing Company, 1968.

Phillips, Victor B. and Gerald Engelman. Market Outlets for Livestock Producers. Agricultural Marketing Service, U. S. Department of Agriculture, Marketing Research Report No. 216. Washington: U. S. Government Printing Office, 1958.

Randell, C. G. Livestock Auctions in the Northeastern States. U. S. Department of Agriculture, Farmer Cooperative Service, Bulletin 8. Washington: U. S. Government Printing Office, 1956.

Templeton, Mary E. Statistical Chartbook of West Virginia Agriculture. West Virginia Agricultural Experiment Station, Current Report 51. Morgantown: 1967.

United States Department of Agriculture. Livestock and Poultry Inventory, January 1: Number, Value, and Classes. Crop Reporting Board, Statistical Reporting Service, U. S. Department of Agriculture. Washingtın: U. S. Department of Agriculture, 1969.

- Packers and Stockyards Act of 19ع1, As Amended. Packers and Stockyards Administration, U. S. Department of Agriculture. Washington: U. S. Government Printing Office, 1967.

Uvacek, Edward and Dalton L. Wilson. Livestock Terminal Markets in the United States. Agricultural Marketing Service, U. S. Department of Agriculture, Marketing Research Report No. 299. Washington: U. S. Government Printing Office, 1959.

West Virginia Department of Agriculture. Annual Reports of Livestock Auction Markets: 1961-1968 (Summary). Charleston: West Virginia Department of Agriculture.

Annual Reports of Livestock Auction Markets to the Commissioner of Agriculture: 1967. Charleston: West Virginia Department of Agriculture.

Annual Reports of Livestock Auction Markets to the Commissioner of Agriculture: 1968. Charleston: West Virginia Department of Agriculture.

Laws of West Virginia Relating to Agriculture and Veterinarians. Charleston: West Virginia Department of Agriculture, 1965, Reprinted from Michie's West Virginia Code of 1961 and 1965 Cumulative Supplement. 
1968 West Virginia Agricultural Statistics. West Virginia Crop Reporting Service, C. R. Bulletin No. 7. Charleston: 1968.

Williams, Willard F. and Thomas T. Stout. Economics of the Livestock-Meat Industry. New York: The Macmillan Company, 1964.

Wootan, Charles V. and John G. McNeely. Factors Affecting Auction Market Operating Costs. Texas Agricultural Experiment Station, B-1056. College Station: 1966. 
Blank Page in Original Bulletin 


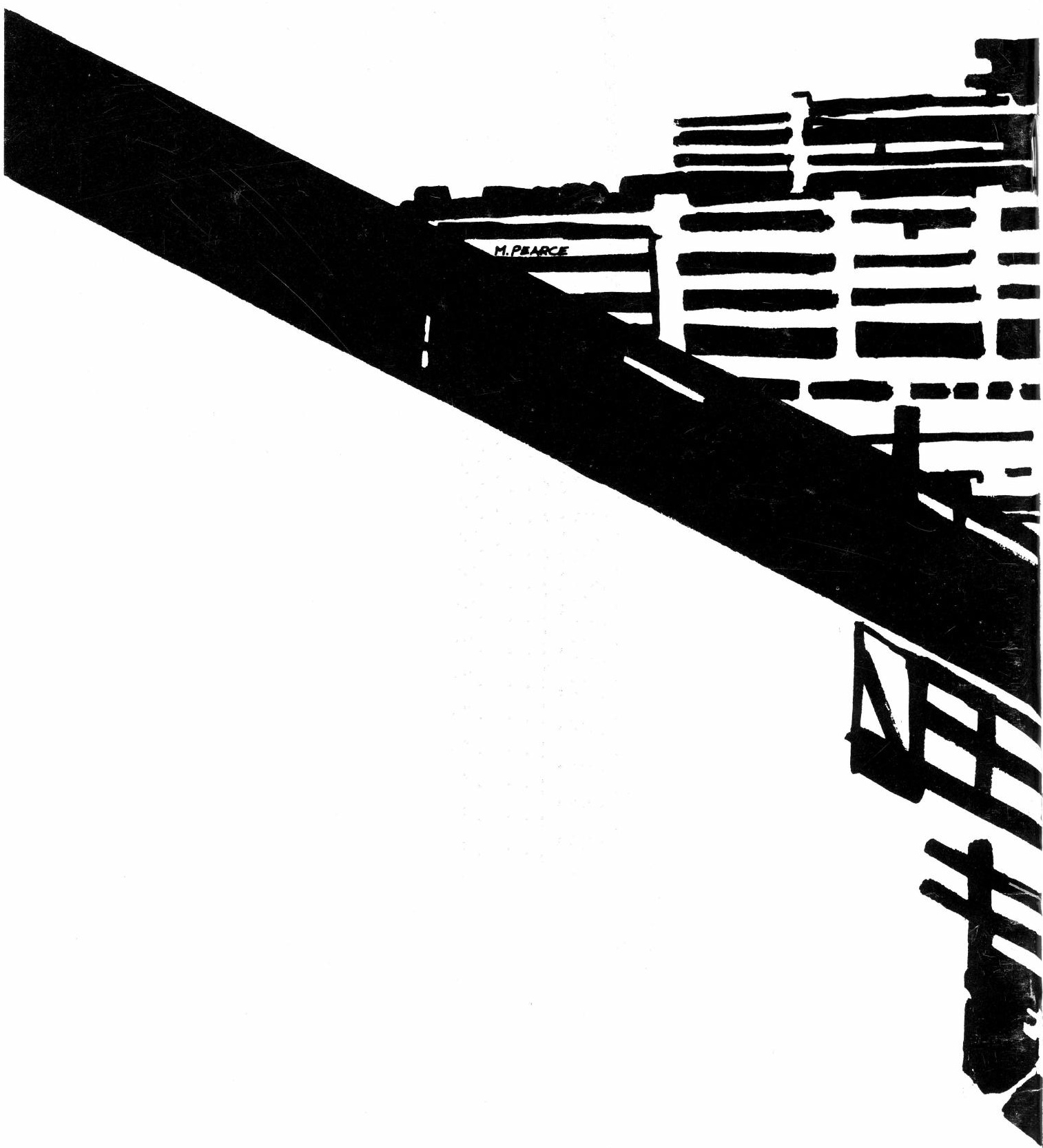

